\section{Briginal $\mathfrak{a}$ rticles.}

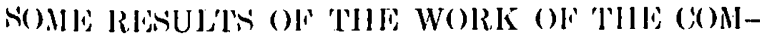
MIITTISE (ON MILK $A$ NI) BABY IIY(IILNE

\section{IN BEIIALF OF BABIJS:*}

IIY JOHN M. CONNOLLY, M.D,, BOSTON

Medical Direrter of the ('ommitte on Milk and Babul Hyjome.

$I_{N}$ order that you may understand the results of the work done by the Committee on Milk and Balny Hywiene in Boston, it will be necessary to make a short explanation of the methods and aims of this organization. The objects of the committee, which is an independent organization, are to provide at, cost pure milk, properly modified, to babies who cannot be fed at breast; to furnish mothers advice and training in the care of babies; to enlighten the public, encourage dairymen and otherwise assist in improving the general milk supply.

There are ten milk stations at present conducted to by the committee. These stations are located: liwo in the North bud, one in the West bind, one in Jistst Boston, one in ('harlestown, one in Cambridgeport, one in Roxbury, one in the South Bay, one at the lineoln House on Smerald Street and one, the Denison House (Central) Station, at ( $i 4-\Lambda$ Tyler street.

$\Lambda$ t these stations detm milk, obtained from lams under the supervision of the commithee, and subject to its rigid inspection, is furnished, at. cost, properly modified in a well-equipped laboratory, in three formulas. Whole milk from

surname, first.

Fiathere's name

Mother's name:
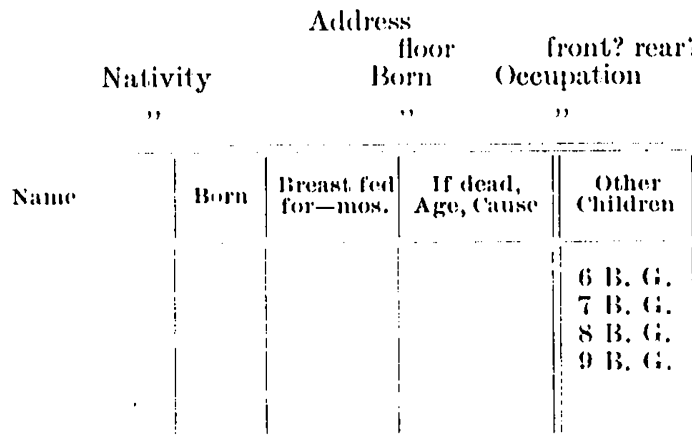

Baby leom alone:?

silecess

C'lothes Propuer

IIaler siuphly

Referred by

Diseases or other almormal eomditions al openting or recomb

Melical $\mathrm{Aill}$ Aerency, intromeded

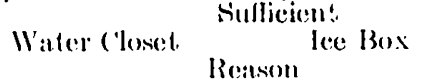

Material $\lambda$ id $\Lambda$ gency, interested

A. ('. Rer'd!?

\section{(ondition of}

Apinturent.

Noturishunent :11:1 Ho:tllh History

the same farms is also furnished lor home modification and for the use of pregrnant and nursing women and of older children, and fat-free milk can be obtained, if desired.

At each station there is a trained nurse who devotes her entire time to the work of the committee, giving out the milk between the hour's of eight and nine every morning, and spending the remainder of the day in visiting the mother's in heir homes.

In each station are held conferences for mothers: the North lind Union Station are hold five weekly; at East Boston and at the Peabody House, each, three; at the Cambridgeport and Court stattions, each, two; at the Charlestown, Roxbury, Lincoln House, South Bay and These are conducted by twenty physicians, who ive their services, without pay, to the work.

To these meetings the mothers are encouraged there the babies are stripped, weighed by the nurse, and examined by the physician in chitrge. Uniform records are kept on cards (specimens of which are shown here) of the child's weight. and ings and the percentages taken. 'To these meetings are brought not only babies who are taking fed babies whose mothers are desirous of availing themselves of oversight in order to keep their babies well. If satisfactory gain is not shown, an effort is made to ascertain the cause of the defect

\title{
(Surname first.)
}

Wt. at birth

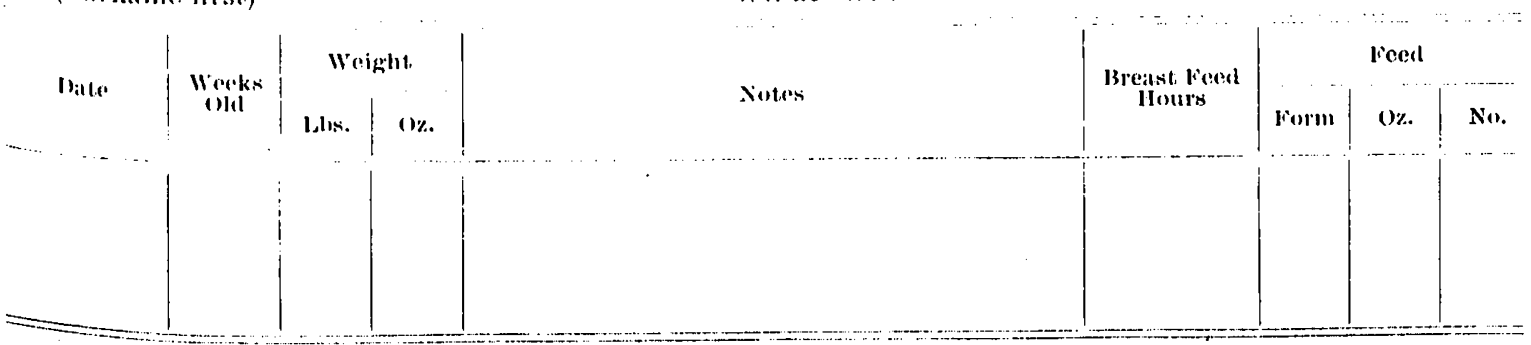

* Read at a meeting of the New England Pediatric Society, Nov. 27, 1909. 
and a change in the formula male, if inclicated. If the haby is not gaining properly, questioning often elicits a story of too frequent, feeding or the feeding of improper substances, and advice suited to the particular case is given.

As in some districts of the eity most of the mothers speak no English, seven ltalian-speaking physicians constitute the staff at the North lind, while the three physicians serving at the West Find are conversant with Yiddish. $\Lambda$ t liast Buston, also, one of the physicians speaks ltalian. Thus these mothers receive instruction in their native tongue and this instruction is made as simple and easy for them to understand as possible.

The conferences are conducted in three different ways: (1) Sometimes the mothers present are addressed collectively, some point of hygiene being taken up, and the talk is often illustrated by a demonstration, as, for instance, the proper method of hathing a baby, the making of barley water, the home modification of milk, the clothing suitable for an infant, with an exhibition of the garments, and so on; (2) at other times the habies are examined one by one in an examiningrom separate from the waiting-room, and advice inclividualized for the particular baby given; but usually, and, best of all, (3) a bahy is examined in the presence of a number of nothers and the alvice given is heard by all the mothers present. In this way mistakes made by one mother are pointed out to her in a kinclly way and made to (lo duty as texts for the education of other mothers, while those who have done well receive approbation and are encouraged to persevere, and the other mothers are persuaded to do likewise. Ind in this connection I will paraphrase a remark of $\mathrm{Dr}_{\mathrm{r}}$. Oliver Wendell Holmes and say that when Mrs. A. gives her baby the breast every hour and a "taste" of potato and a little store milk, and the balny becomes sick, we have three experiences to take into consideration: First, the reries of events as they actually occurred; second, Mrs. A.'s interpretation of these occurrences, with her deduction that the bahy has become sick, let us say, from "teething"; and, third, the interpretation of the same events by an educated physician whose opinion regarding cause and eflect maly be widely at variance from Mrs. $\Lambda$.'s opinion. Now it is well known that any woman who ever brought up a baloy, and particularly any woman who has lost a baby, has a strong impulie to act as a teacher to her less competent sister's and to give them the "benefit" of her experience, often to their great disadvantage. One of the doctors engaged at the stations stoutly maintains that, one mother informed him that he couldn't tell her anything about babies or sick babies, for she had had six before this one and had buried every one of them. In these confercuces for mothers, Mis. $\Lambda$.'s experience with her baby as seen by the eye and interpreted by the trained mind of an educated physician is made available for the benefit not only of Baby A., but of many others, so that each aids all.

sick babies are not treated at these confer- ences, but when such are found they are referred to the family physician, or, if the parents anc indigent, to the district, physician or to a dispensary or hospital clinic. Our attempted task is to keep babies well by advice, by oversight, by encouragement of breast feeding, by instruction of the mother's in the rules of hygiene and by furnishing at cost, in sterilized feeding bottles, fir'st-class milk, properly modified, as well as whole milk for home modification; and. our object is promoted in a very effective way by our follow-up system of nurses' visits to tho homes. The nurse is expected to visit the home of each baby under her care at least once a week, and there reinforce the advice given by the physician in the conferences. The nurse cndeavors to secure proper care of the milk, sceing to it that the milk for the infant is kept cold and protected from dust and flies, instead of being allowed to become warm and to be exposed on a window-sill or elsewhere. She tries to secure proper hygienic conditions in the homes she visits where the conditions are unhygienic, and to that end violations of the building code or of the health laws are reported to the Board of Health. Cases of reportable discase in adults are occasionally detected and reported, and some consumptive patients have, through the efforts of the nurses, been placed in more suitable quarter's, and the young children protected in a measure from the danger of infection. The importance of cleanliness and of fresh air has been emphasized, and the many little devices for lessening work in caring properly for an infant have been taught where it is alone practicable to teach them - in the homes. The home modification of milk is explained and re-explained and the nurse sees that, the mother does it properly. 'The importance, and value of the nurses' work can only be hinted at in the short time at my disposal, but they must be evident from the few points which I have indicated. Our nurses are forbidden to visit houses in which there are patients suffering from any contagious disease, and they do not, visit sick babies to care for them. As soon as a baby becomes sick, it is referred, as I have stated, to a physician or a dispensary. The committee's nurses offer their services to the physician in charge of the case for the purpose of securing, if desired, one of the nurses from the Instructive District Nursing Association to visit and care for the child in the home, under the direction of the physician in charge of the case, and they themselves abstain from earing for the sick child until notified by the district nurse that the baby has recovered. In this way duplication of effort is avoided and the elosest (o)-operation is effected.

Many of the babies are sent to us by privale physicians or physicians on service at the varions clinies, and the work of the station is in these cases limited to the proper filling of the prescription and to secing that the milk is used properly at the indieated intervals and in the prescribed amounts, and to the enforcement of the general rules of hygiene.

Prescription cards are furnished to physicianss 
on application and all such prescriptions must be renewed in one month at the latest; and if at any time the baby is not doing well and gaining properly, he is at once referred back to the physician whose prescription he is taking. We feel confident that by this procedure some casses of more or less serious disease have been prevented by enabling physicians to deal with slight disorders in their incipiency. I personally can testify to the great relief $I$ have felt in knowing that a patient for whom I have preseribed a formula at, the Dispensaly will be followed up in the home by a nurse trained to instruct the mother in the proper care of the child, and I can also testify to the great improvement in the results and the more intelligent attitude of the mothers that I have noted since these nurses have been available, as compared with the period before they began work.

Of the education of the mothers by means of poster's and other printed matter distributed to them, I shall not take the time to speak, but will pass around specimens of the various forms which we have issued in three languages, as well as of the record carrets and prescription blanks which we use. Any helpful criticism of these or any arlviee which any of you can give regarding them will be much appreciated.

\section{MILIT S'TATIONS}
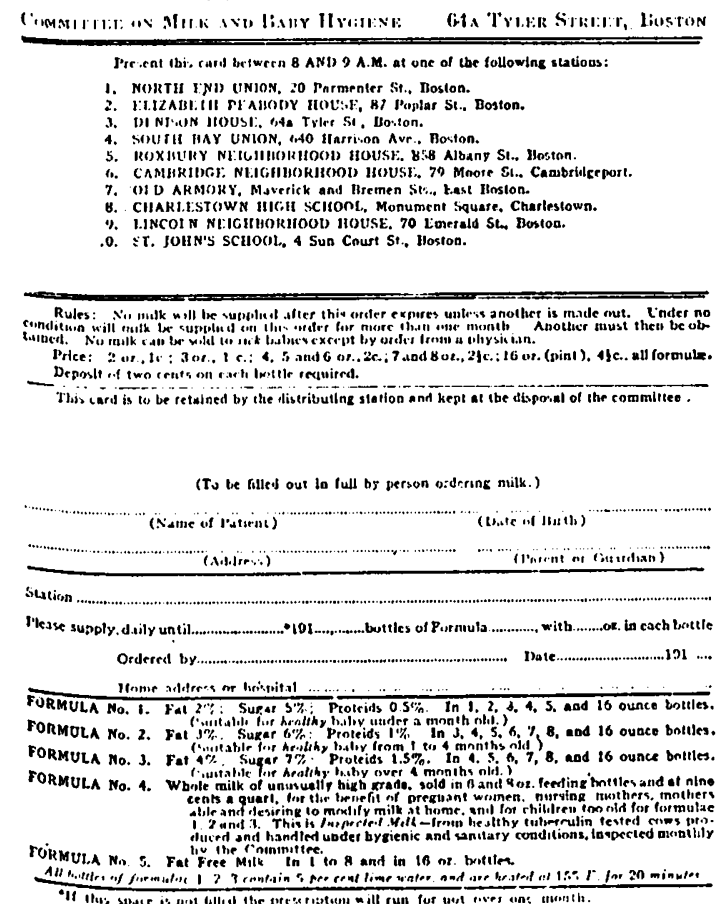

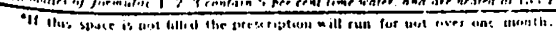

1 an walching with much interest an attempt we are making to enlist the fathers and obtain their active co-operation in securing proper hygienic surroundings and care for their infants, by means of meeting's for fathers, conducted by the physicians that attend the conferences for mothers, and by others, at which the importance to the infant of the care and proper treatment and nourishment of the expectant mother and of the nursing mother is made eleatr, and other suitable topics discussed.

I desire to refer to the experiment, which is being made at the Charlestown Iligh School, where thirty-eight girls of the upper clisses are receiving instruction along these lines, from the physician in charge of the station there, application for admission to this classs having in every casse been made by the parent.

One important line of our endeavor is the effort of the physicians who are doing this work to educate themselves somewhat further along right lines, through an organization which they have effected, of which the honored president; of this society is president, and the occasional meetings of which are addressed by an expert on a topic germane to the work in which they are mutually interested.

We come now to a consideration of the results of the endeavor, and I may say at the outset that conclusions drawn from one year's effort, or even several year's' effort, must ho aceepted with very great reserve. We hegan these consullations June 24, 1909), and have had numses in the stations but litte longer than that. It is as easy to become too enthusiastic over apparent, suecess as to become disheartened too easily ovel apparent failure, and there is danger of attributing to our exertions results which may flow from altogether different sources, such as the influence of weather conditions and other causes. Partienlarly is care to be exereised in comparing the stalistites of one year with those of another, and I refer more particularly to the eomparison of the figures for this year with those of last year, because the number of deaths of infants under one year of age in Boston, as may be seen from this chart, kinclly loaned me by Mr. John Ritchie, of

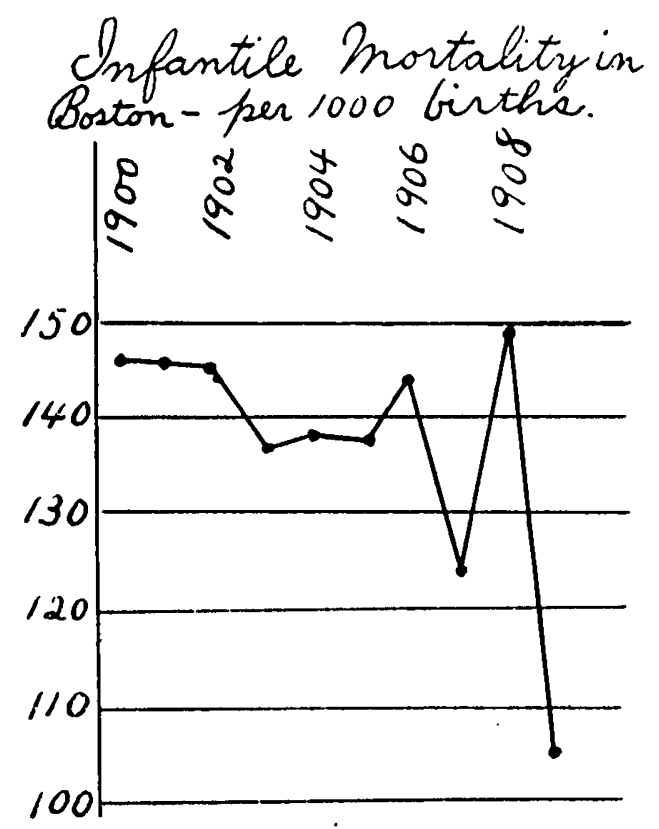

the Boston Board of Health, who prepared it for his address before our Association of Physicians: of the Mothers' Conferences, suddenly rose in 


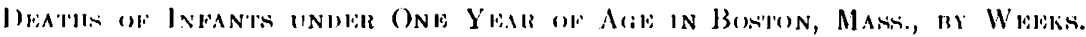

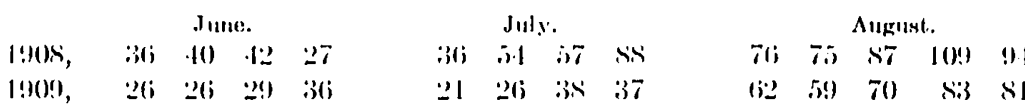

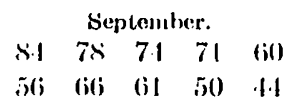

Tor:1

I.1Si

S71

Rerduction in l!90!),

tous to a point higher than hat been reached for in 1909, and the number of deathe of babies under several year's previously.

But making all due allowances, and eliminating all thought-of factor's of error', after having given much time to the eollecting of statisties and much (atre 10 the consideration of them, I (b) not, hesitate (o sity', indeed l feel that. I am very conservative in saying, that I know that we have done much good and that we have had our share - a not unimportant share-together with other agencies, in adding toward the marked diminution in the infautile mortality of Boston, which is shown in the above table:

One of the chief sources of our success, it seems to me, has been that everywhere, in the conferences and at the homes, our physicians and nurises have emphasized, first of all, the value of breast milk for the human infant, have exercisel the greatest care to keep babies on the breast, when that was at all possible, and have prevented their being taken off the breast through the valued aid of the Boston Provident Associattion, who have, in several instances, furnished pensions for women who would otherwise have been forced by poverty to deprive their babies of an abundant supply of breast milk. I am glad of this opportunity to cxpress in this public way the appreciation of the committee for their generous, wise and prompt assistance.

(ne of the results of which I am most proud is that, of the $80+4$ babies which we have had under our supervision, so who came to us on a mixed breast and cow's milk diet we were able to replace on exclusive breast feeding and by so doing to secure more satisfactory gain than before, by furnishing milk to the mother's and by seeing $t o$ it that they earried out the advice given regarding regularity of nursing and their own diet and hygiene.

The following table shows the total number of deaths during the same period of infants under one year of age in Boston, by wards, taking only these walds in which we have stattion serviee.

\begin{tabular}{|c|c|c|c|}
\hline Wartl. & 1908. & 1900\%. & Difference. \\
\hline 1 & 14 & 27 & 17 \\
\hline 2 & .1:3 & $\ddot{2}(j$ & 27 \\
\hline$: ;$ & 21 & 17 & 7 \\
\hline .1 & 19) & 2.1 & $i$ \\
\hline$\vdots$ & 21 & i.; & ii \\
\hline (i) & $\therefore$ & is & 26 \\
\hline 7 & 20 & 11 & $!$ \\
\hline is & ז & is & 10 \\
\hline ! & :i? & ini & :3 \\
\hline 10 & 11 & ii & j \\
\hline 11 & ! & 11 & 2 \\
\hline $1: 2$ & Iij & $\because(1)$ & 1 \\
\hline $1: 3$ & 67 & 11 & $\ddot{2}(\mathrm{i}$ \\
\hline 1.1 & 38 & 2.5 & 11 \\
\hline
\end{tabular}

The following table enables a comparison to be male between the number of deaths of infants under one year, by wards, during the same period the care of the committee in the same wards. It will be noted that some of the stations operate in more than one ward, and that some wards are served partly by one and partly by another station.

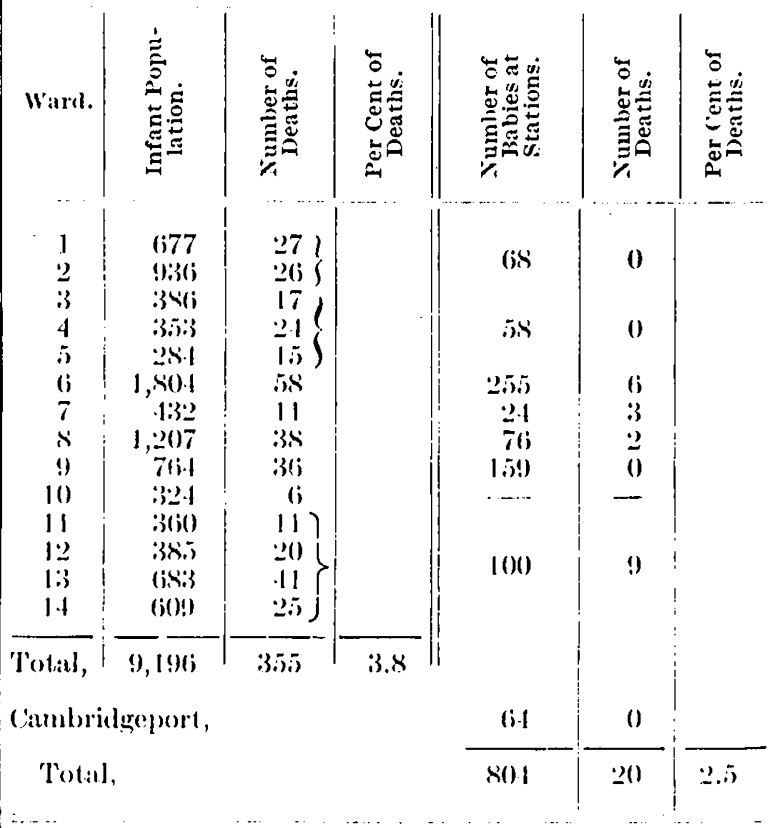

We have had an interested group of mothers in regular attendance on the conferences, as the following table will show.

Name of Station.

1)enison Iotuse

leabody House,

South Bay Union,

North Find Union,

Roxbury Neighborliond House,

('ambridge Neighborliood Howse,

Sun Court (Aliar.-Fiept.),

( )l Armory, bave Jostom,

('Harlestown J Jighl Sichool,

I incoln Ilouse,

\begin{tabular}{|c|c|}
\hline $\begin{array}{l}\text { Number of } \\
\text { Comferences. }\end{array}$ & $\begin{array}{c}\text { Averuge: } \\
\text { Attendlance. }\end{array}$ \\
\hline IS & $1: 3$ \\
\hline 28 & 15 \\
\hline 17 & 1:3 \\
\hline $7 \%$ & 12 \\
\hline 15 & 8 \\
\hline $1: 3$ & 15 \\
\hline (1) & $\therefore$ \\
\hline $2 !$ & $s$ \\
\hline 11 & 16 \\
\hline 1.1 & 7 \\
\hline
\end{tabular}

Of our s(0.1 babies, 20 have died since June 1 , I!H9, a deatli-rate of $2 ! \%$. During the same period the number of infant deaths in the eity was 571 , a percentage, computed on infant population, of $\therefore 1 \%$, and the number of deaths in the wards reached by our stations was 355, a percentage, computed on ward infant population, of $3 . S^{\prime \prime} \%$.

But I hesitate to make such comparisons, for the reasons I have already stated. The more important results of this work can be understood only from a knowledge of the methods under which it is conducted. They are to a certain extent incapable, as yet, of being reduced to figures, but are not, on that account, the less real. 
They are educational in scope and character and, like all educational efforts, show results at a period more or less remote from the time of their inception. Immediate results we have seen, and in plenty, as I have demonstrated, but the larger results, which we believe must follow, can yet be seen only with the eye of faith. We have made a beginning, but it is only a beginning. We have gathered it certain amount of valuable statistical material, which hats the unusual merit of being fairly aceurate. What this will teach us ean only be determined by a comparison with the information of next year and the year after and the year after. But wherever it leads us we are determined that we shall keep the open and unprejudiced seientific mind.

We have made many valuable mistakes, valuable because they now serve us as guideposts pointing to the right way. We are prepared to do more eflective work thim heretofore because of these enrors. And we have accumulated a fund of invaluable experience in the light of which we are beginning clearly to see that in this problem of infant mortality are involved problews of $\mathrm{i} g-$ morance, of poverty, of cupidity, and that there is need of hringing to their and its solution the united experience and wisdom of philanthropists, of hygienists, of pediatricians, of social workers, of milk producers, of statisticians; that, as Dr. Rotch remarked in his address before the last meeting of the American Pediatric Socicty, "the intelligent solution of these problems can only be accomplished by making use of the combined knowledge of each student in his own particular province of research."

It will be noticed that, of the ten stations, five are located in settlement houses. The nursing service at two of these is supplied through the settlement organization, and the assistance and influence of these neighborhood organizations has been largely instrumental in the rapid growth and substantial establishment of the committee's work there.

I am often asked the question: What is the committee? It is an independent, self-constituted group now numbering thirty-seven. The chairman is Mrs. Mary Morton Kehew, President of the Women's Educational and Industrial Union; Dr. Walter 13. Cannon, Professor of Physiology in Harvard Medical School is Secretary; Mr. Arthur II. Brooks, an attorncy, is Treasurer. It embraces the Professor of Preventive Medicine at Harvard, the presidents of the Associated Charities, Children's $\Lambda$ id Society, Floating Hospital, New England Pediatric Society and the Massachusetts Red Cross; the chairmen of the Board of Health, the Children's Institutions Department, the Health Committec of the Women's Municipal League, the Chief of the Boston Milk Inspection Bureau, the headworkers of five social settlement houses and the executives of several of the principal charitable societies, ten teachers in Buston medical colleges and last, but not least, five practical dairymen.

We have, therefore, fully realized that it is only through co-operation, co-ordination and combi- nation that the problem of infant mortality can in its essence be dealt with, and we are beginning to see our own opportunity to act as a clearinghouse, to become the means of uniting all these clifferent helping agencics of Buston into an irresistible phalanx of workers for the babies' sake, and we hope that we shall be big enough and broad-minded enough to rise to the opportumity that is beckoning to us here and now.

For the benefit, of those physicians who are interested in the work of the milk stations, 1 append a short

HLHLLGHAPY.

Budin: Resultats obtenus var les consultations deq nourrissons. liobstétrique, $1905,13 d$. 10, $\$$. 309 . J.es consultitions des nourrissons. Arch gén. de méd no. 20; 'Rev. d'hyg. ot de mot inf., 1905, Bd. 4, 9. 117. Des consultations de nourrissons, leur wultats. Lobstétrique, juli, 1006

The New York Milk Committee: Infants' Milk Depots and their elation to Infunt Mortality.

Variot: La mortalité mfuntile dans les consultations des nourrixsons. Abus de la statistique. Clin. inf., 1905, Bd. 3, 3.353 . Sur

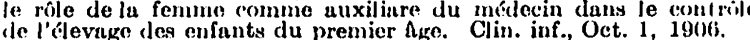
Celevage des enfants du premier nere. Clin. inf., Oct. 1, 1906. children. Am. Med., Dec. 19, 1903.

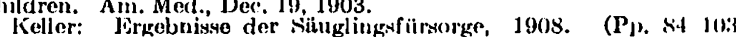
(ont:iin full hibliography.)

\section{THE IOA(INOSIS AND TREATMEN' ()W INTUSSUSCLP'IION.*}

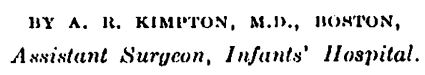

InTussuscerron is essentially a clisense of childhood and is only spoken of here as such. The diannosis of intussusception is the mother's story, practically, every time. In hardly any other disease is this so often true. Usually, the mother will say that the baby was perfectly well, when suddenly he began screaming, turned pale and vomited, but got better very quickly. After that the baby was fussy, eried and apparently had pain at intervals, with straining. Soon after the first sharp pain the bowels may have moved. Usually intestinal peristalsis has been marked in these children, with considerable gas. After a few hours, usually within the first twelve, the mother notices that there is blood in the stools, and, almost invariably, it is now that she sends for the doctor, and it is now that he should make the diagnosis, on his first visit. Here is where the child's life is saved - at the time of the doctor's first visit - and it is the attending physician who really saves these babies. It is a great mistake to half listen to the mother and then not at all consider her story. Tou often is the mother's story disregarded in these cases. At the beginning these cases look as though nothing was wrong with the baby. It may have a normal temperature and pulse. Later the temperature is usually sub-normal, with increased pulse-rate. This fact is what misleads, but it is in these first hours that the diagnosis should be made. It is easy enough after twenty-four to thirty-six hours have passed.

With the history alone of a previously well child suddenly beginning to scream, turning pale, vomiting; then a quick recovery, cramps, strain-

* Rend at a meeting of the New lingland Pediatric: Society, Nov. $27,1009$. 